\title{
The Construction of the Special Course of Automobile Electronic and Electrical Equipment
}

\author{
Peijiang Chen \\ School of Mechanical and Vehicle Engineering \\ Linyi University \\ Linyi, Shandong, China \\ chenpeijiang@163.com
}

\begin{abstract}
Course construction is one of the important contents of quality engineering in colleges and universities, and it plays an important role in improving teaching quality. Taking the course of Automobile Electronic and Electrical Equipment of Linyi Un iversity as an example, the research and practice of the special course construction are carried out. The development process of the course is introduced and the course system is analyzed. The organization of teaching contents, including theory teaching, practice teaching, course design and extracurricular innovation, are discussed. A variety of teaching methods are used flexibly in the teaching process, which contributes to the cultivation of students' innovation ability and application ability.
\end{abstract}

Keywords-Automobile Electronic and Electrical Equipment, special course, course system, teaching method

\section{INTRODUCTION}

Linyi University has several automobile majors, including vehicle engineering, automobile service engineering undergraduate majors and automobile application technology specialty. The Automobile Electronic and Electrical Equipment is an important professional course in the automobile majors. It has manifested the achievements in the content reform, including the vehicle engineering key major in the applied talents training characteristic school project of Shandong province, automobile detection and maintenance teaching team of Linyi University [1], entrepreneurial talent training mode experimental area in automotive service field of Linyi University. The course occupies an important position in the course system of the automobile majors.

The electrical appliances are the important parts of an automobile, which is the important teaching content of the professional curriculum system since the vehicle engineering major was established. The course of Automobile Electronic and Electrical Equipment has been a separate lesson from 2007. With the development of electronic technology and computer technology, the updating speed of automobile electrical appliances and control devices have been greatly accelerated. Accordingly, the course teaching content has been updated, and the contents of automobile electronic control have been added to the course teaching. At the same time, the course design of Automobile Electronic and Electrical Equipment is added, which can strengthen the students' abilities of comprehensive use of professional knowledge, problem analyzing and problem solving.

In order to improve the students' practical ability, the Automobile Electronics Lab is established, and the experimental practice equipment is continued to improve. The combination of theoretical teaching and practice experimental operation lays a solid foundation for the talent training for the automobile electronics industry development.

After ten years of construction, the course teaching team has basically achieved the goal of rational construction of teaching staff, teaching content optimization, advanced teaching methods and high teaching quality. It was appraised as the school-level special course in 2014.

\section{COURSE SYSTEM}

Linyi University targets at being a nationally known innovative and entrepreneurial university with distinctive regional feature, and it is committed to cultivating high-quality applied talents with Yimeng spiritual characteristics and international vision [2]. Closely around the regional economic development, in accordance with the actual needs of talent for the enterprises and institutions, the major of vehicle engineering trains the talents with solid basic theory, innovative spirit and practical ability, strong professional quality. The graduates can engage in automobile design and manufacturing, testing and maintenance, usage and management, and so on.

The prerequisite courses of Automobile Electronic and Electrical Equipment include Circuit Analysis, Electronic Technology, Automobile Construction, Engine Principle and other professional basic courses. The follow-up courses are Automobile Maintenance Technology, Automobile Detection Technology, and other professional courses. It is very important, serving as a link between the past and future courses. The course can guide students to learn the knowledge of automobile electrical and

This research was supported by the Teaching Quality Engineering Project of Linyi University, Shandong, Chi na, in 2014 and 2016. 
electronic control, cultivate students' enthusiasm and interest in learning [3]. The basic concepts, basic theory and analytical methods of this course play an important role in inspiring students' thinking and improving their innovation ability.

The course of Automobile Electronic and Electrical Equipment has complete system, and it has the characteristics of system theory and strong practice $[4,5]$. The teaching content is composed of two parts: theoretical teaching and practical teaching. It provides the professional knowledge and skills of automobile electrical and electronic technology for students of automobile specialties. It mainly teaches the structure, composition, working process and working principle of automobile electrical circuits. The students can master the electrical circuit fault detection and diagnosis technologies, find the fault through analysis, so as to solve the problem of automobile electrical and circuit maintenance.

By studying this course, the students can understand the domestic and foreign development trends of automobile electronics and electronic technology and master the basic principles and laws of automobile electronics and electronic equipment. It trains students to use modern equipment for automobile electrical and electronic systems for testing, diagnosis, and have a certain degree of technological reform and innovation ability.

The teaching objectives of this course are as follows.

(1) Knowledge training objectives: to master the composition working principle and development trend of the modern automobile electrical and electronic systems.

(2) Capacity training objectives: to be skilled in the use of automobile electronic detection tools and related equipment, master the maintenance, adjustment skills of electrical and electronic systems and automobile electrical design methods, and to be adaptable for the future development of the automobile technology.

\section{TEACHING CONTEnT ORGAnization}

The teaching content of this course has the characteristics of fundamentality, applicability and forwardness. At the same time, the teachers should introduce the latest development achievement and teaching research results into teaching. According to the course chapters, a variety of teaching models can be used.

\section{A. Theory Teaching}

The theory teaching contents of this course has 32 class hours, as shown in Table 1.

TABLE I. THE THEORY TEACHING CONTENTS OF AUTOMOBILE ELECTRONIC AND ELECTRICAL EQUIPMENT

\begin{tabular}{|c|c|c|c|}
\hline Chapter & Theory hour & Experiment hour & Total hour \\
\hline Battery & 2 & & 2 \\
\hline Alternating current generator and voltage regulator & 4 & 4 & 6 \\
\hline Starter & 4 & 2 & 6 \\
\hline Ignition system & 4 & 2 & 6 \\
\hline Lighting and signaling system & 2 & 4 & 2 \\
\hline Instrument and display system & 2 & & 2 \\
\hline Auxiliary electrical equipment of automobile & 2 & & 2 \\
\hline Automobile circuit analysis & 4 & & 2 \\
\hline Electronic control systems of engine & 2 & & 6 \\
\hline Electronic control of transmission system & 2 & & 48 \\
\hline Electronic control technology of chassis & 2 & & 2 \\
\hline Total circuit of automobile electrical equipment & 2 & & 6 \\
\hline Total & 32 & & 6 \\
\hline
\end{tabular}




\section{B. Experiment Teaching}

The experiment teaching of this course has 16 class hours. The main projects include: the testing and disassembly of alternating current generator, the disassembly and detection of starter, the disassembly and detection of ignition system, the awareness and maintenance of lighting, signal, auxiliary electrical system, and so on.

\section{Course Design}

On the basis of mastering the structure and principles of automobile electronic and electrical equipment, the course design requires students to understand the circuit design methods, rules and applications of automobile electronic and electrical equipment, meeting the demands of teaching, research and production, training students' problem analyzing and solving.

\section{Extracurricular Innovation}

For the excellent course assignments or course design, the teachers summarize them and encourage students to participate in various types and levels of extracurricular competitions, improving students' innovative entrepreneurial ability and comprehensive application ability.

\section{TEaching Methods And Means}

As the course of Automobile Electronic and Electrical Equipment has strong theory and practicality, and it has many knowledge points and fast update speed, the course teaching focuses on training students' practical ability. In the teaching process, with the work task as carrier, the teachers can use case teaching method to inspire students to learn, stimulate interest and potential, and improve teaching effectiveness.

Aiming at the content features and teaching requirements of different sections of the course of Automobile Electronic and Electrical Equipment, a variety of teaching methods are combined to fully mobilize the enthusiasm of students. The effective methods include on-site teaching, discussion method, module training method, fault simulation method [6], and so on.

\section{A. On-site Teaching Method}

In the classroom, using the advantages of multimedia courseware, the structure of automobile electric equipment can be displayed in front of students to improve student interest in learning. In the laboratory, the teachers explains based on the equipment to increase the students' perceptual knowledge and improve the lecture effect.

\section{B. Discussion Method}

In the teaching process, the teachers set the discussion, focusing on the important knowledge to develop students' ability of solving practical problems.

\section{Module Training method}

Aiming at the module of strong applicability, the teachers demonstrate the operation, students train themselves. The step by step teaching methods is used, the step is basic skills training, special ability training, technical application ability training. It reduces the teaching cost and improves the teaching effect.

\section{Fault Simulation method}

In the practical teaching, the fault simulation method is adopted. The students can think and discuss deeply which improves the students' practical ability.

In the whole teaching process, the above teaching methods are selectively adopted based on the teaching contents and teaching conditions. It can make teaching content be more closely linked with practical situation. The teaching pays more attention to the training of the students' ability of innovation and practice.

\section{CONCLUSIONS}

Through the joint efforts of all members of the course teaching team, the course of Automobile Electronic and Electrical Equipment has formed a complete teaching system, including teaching, answer question, practice and other links. The course construction has achieved remarkable results. The students have higher evaluation on the teaching situation and the peer teachers, leaders and experts give praise. Most of the students have produced strong interest on the course learning. They not only learn the professional knowledge, but also timely understand the frontier scientific results of automobile electronics technology, and they make a positive evaluation for the course teaching. The course has good application. A considerable number of graduates take automobile electronics technology as the graduation design theme or means. The course also lays good foundation for participating in various competitions. It can improve the students' practical ability and enrich the employment skills. 


\section{ACKNOWLEDGMENT}

This research was supported by the Teaching Quality Engineering Project of Linyi University, Shandong, China, in 2014 and 2016.

\section{REFERENCES}

[1] P. J. Chen, Research and Practice of Construction of Automobile Detection and Maintenance Teaching Team, Advances in Social Science, Education and Humanities Research, vol. 25, pp. 152-155, January 2016.

[2] X. H. Jiang, P. J. Chen, Study of Problems and Solutions in Innovation and Enterprise Education of Engineering Specialities, Advances in Social Science, Education and Humanities Research. vol. 25, pp. 156-159, January 2016.

[3] W. H. Wang, W. H. Yu, National Classic Course - Electric Equipment in Automobile, Journal of Xingtai Vocational and Technical College. vol. 21, no. 3, pp. 11-12, June 2004.

[4] Z. Song, Y. Feng, View of Construction of National Top Quality Curriculum for Automobile Electron Control, Journal of Wuxi Institute of Technology, vol. 4, no. 4, pp. 1-3, December 2005.

[5] G. H. Tian, The Construction and Application of Excellent Resources Sharing Course, Journal of Sichuan Vocational and Technical College, vol. 27, no. 1, p. 146-148, February 2017.

[6] X. Mi, P. J. Chen, Research on Project Teaching of the Course Automobile Electronic and Electrical Equipment, Adva nces in Computer Science Research, vol. 25, pp. 528-531, September 2015. 